\title{
Organizational Climate at the Jordanian Public High Schools and its Relation to the Teachers' Job Performance
}

\author{
Rateb S. Al-Saud ${ }^{1} \&$ Khitam N. Radwan ${ }^{2}$ \\ ${ }^{1}$ Prof in Educational Leadership, Faculty of Educational Science, University of Jordan, Amman, Jordan \\ ${ }^{2}$ Ministry of Education, Jordan \\ Correspondence: Khitam N. Radwan, Ministry of Education, Jordan. E-mail: khitam.radwan@yahoo.com
}

Received: April 2, $2018 \quad$ Accepted: April 10,2018 Online Published: April 28, 2018

doi:10.5539/mas.v12n5p77 URL: https://doi.org/10.5539/mas.v12n5p77

\begin{abstract}
This study aimed at identifying the organizational climate at the Jordanian public high schools and its relation to the teachers' job performance. The sample of the study consisted of (100) high school principals, who were chosen using the stratified random technique, and three teachers who work with each of those 100 principals, who were chosen randomly, during the academic year 2016-2017.

The findings of the study indicated that both of the organizational climate and job performance at public high schools in Jordan was medium. Furthermore, the results indicated a statistically significant positive correlative relationship at $(\alpha=0.05)$ between the level of the organizational climate in the public secondary schools in Jordan and the level of teachers' job performance in these schools. Accordingly, the two researchers recommend that the Ministry of Education should improve the organizational climate in secondary schools in Jordan and hold training courses for principals in this field.
\end{abstract}

Keywords: organizational climate, job performance, public high schools, Jordan

\section{Introduction}

Public High School is one of the important institutions that seek to build human- being. In these schools, the principals seek to create a warmth organizational climatein order to achieve the goals of the Ministry of Education, as well as his responsibility in finding strong relationships between the school and teachers to upgrading their job performance.

The organizational climate is defined as "internal factors that control the individuals' behaviours, and distinguish them from other organizations". Some of these factors are: organizational structure, traits of principal, relationships between teachers and school administration, relationships of teachers with each other, and the ability of organizational climate in influencing teachers to change their motivation and behaviour in order to strengthen their points of power, and correct negative points in order to achieve the school's goals (Hamadat, 2008).

Abu Sawirah (2010) argued that there are various factors affecting the organizational climate, including external factors; the climate technology has the greatest impact, the social climate that indicates the school relationship with local community, and the organizational factors, which are classified as internal climate of the school. However, the personal factors that can affect the organizational climate relate to individualism for teachers of where they accept the organizational climate within the school and their job performance.

Farrouj (2011) noted that the organizational climate in high school has two main dimensions. The first relates to administration's interaction with teachers. The second relates to teachers' interaction with each other in terms of distribution of tasks among them and cooperation in their achievement.

The organizational climate within the high school consists of several types:

1. Open organizational climate: Teachers in which can enjoy a high moral spirit, and the future that is characterized by seriousness in disciplined job performance that relations between teachers are weakened, control and errors clutching are plenty used within, technology is rarely used, as well as paperwork is plenty used.

2. Family organizational climate: In this type, tasks and responsibilities are distributed, with more production, 
and greater performance.

3. Closed organizational climate: in which the principal is authoritarian and characterized by dictatorship and centralization in taking decisions.

The organizational climate is the internal work climate with all its human elements: teachers, principals and staff. The organizational climate is the personality of the school, which is clearly reflected in the teachers' sense of trust and participation that reflected in their performance. The organizational climate has a significant impact on the job performance of teachers. Job performance is "the effort that an individual makes within the organization in order to achieve its goals and this performance may be behaviour, effort, or work" (Abu Sawirh, 2010).

Job performance is an inevitable result of a combination of factors: individuality, motivation, organizational climate, achieving work in meritorious and faculty aptitude, and high school teacher aim at improving his or her performance. It is a behaviour or effort that leads to a result whether want to do the work assigned to him or not. Hence, performance will be a response, as multiple performance elements are available, which is the knowledge of what required by teacher to do within his job, his skills and knowledge about them, quality of work, what he want to make to the fullest, amount of work completed, and what he is required to achieve in normal circumstances, as well as his urgently accomplishment (Hamad, 2016).

The teaching process requires a good organizational climate, in which teachers enjoy health organizational so that their performance can be positive. Each educational institution seeks to be distinguished, with outstanding performance, and this excellence can only be achieved through the availability of a sophisticated organizational climate and distinguished teachers seeking to develop and innovate their performance to reach progress.

Through the observations and work of the two researchers in the public high schools in Jordan, they found that most of public high schools in Jordan suffer from the absence of the positive organizational climate. This phenomenon creates a deep gap between principal and teachers that affect the internal climate of the school, leading to a weak job performance of teachers. Despite of many previous studies on organizational climate and job performance of teachers, the two researchers did not find any study who attempted to explore the relationship between organizational climate and teachers' job performance in the public high schools in Jordan. So, this study came to fill this gap.

\subsection{Problem of Study}

The two researchers noted that there is a fluctuation in the level of organizational climate in secondary schools in Jordan, and many of them suffer from the low level of this climate, which negatively affects the performance of teachers. Therefore, the problem of this study is determined by answering the following question:What is the level of organizational climate at public high schools in Jordan, and how it relates to the level of teachers' job performance?

\subsection{Objective and Questions of Study}

The study aimed to identify the level of organizational climate at public high schools in Jordan and its relation to the job performance of teachers. To achieve this goal, the study attempted to answer the following questions:

Question 1: What is the level of organizational climate at public high schools in Jordan from teachers' perspective?

Question 2: What is the level of job performance of teachers at public high schools in Jordan from principals' perspective?

Question 3: Is there a statistically significant relationship $(\&=0.05)$ between the level of organizational climate at public high schools in Jordan, and the level of job performance of teachers in these schools?

\subsection{Importance of Study}

The importance of this study stems from the importance of its two subjects, namely: school organizational climate and teachers' job performance. The researchers hope that the results of this study will benefit the following entities:

- $\quad$ Ministry of Education: In terms of developing educational policies that ensure good organizational climate is available, and mostly avail of human potential of high school teachers, reconsidering the structure of school regulations to achieve the job performance, and sustainable development of faculty members of teachers.

- Public high school principals: By taking care of the organizational climate in their schools, and thus increasing the level of job performance of their teachers. 
- $\quad$ Researchers: by providing them with a theoretical framework on organizational climate, job performance, and study tool.

\subsection{Definition}

Organizational climate: It is defined as "traits or characteristics found in the work climate that make them unique to other institutions. It is the result of all internal environmental interactions that are evident in behaviour and performance of high school teachers." It is a set of factors and characteristics that guide and regulate the behaviour of individuals within the organization distinguished from others"(Hamadat, 2008).

The researchers define school organizational climate operationally as the traits and methods that can make the internal and external school climate special, on which the values and trends of the high school teachers are reflected. It can be measured by responses of members of study sample on the study questionnaire which developed by researchers for this purpose.

Job performance: is the "effort made by the individual within the organization to achieve the goals" (Hamad, 2016).

The researchers define job performance operationally as the effort of teachers of public high school in terms of teaching responsibilities within their schools in order to achieve educational goals of the school. It is measured through the responses of the study's sample members on study questionnaire developed by researchers for this purpose.

\subsection{Limitations}

This study limited to teachers and principals of Public high schools at Zarqa Education Directorate II, Jordan, during the academic year 2017-2018.

\subsection{Previous Related Research}

In this section, the researchers present some of the previous studies related to the organizational climate and its relation to job performance, ranked from oldest to newest, as follow:

\subsubsection{Arabic Studies}

Abu Sweireh (2010) implemented a study entitled, "The impact of the organizational climate on job performance of administrative staff at Islamic University in Gaza". The sample of the study consisted of 180 employees. The results of the study showed a positive organizational climate in the university. There were no statistically significant differences due to gender, age, experience and place of work.

Al-Omari\& Al-Ta'ani (2013) conducted a study entitled, "The impact of organizational climate on job performance of teachers in Irbid Governorate". The sample of the study consisted of 431 teachers. The results showed that the degree of influence of organizational climate on job performance was medium, and that there were not statistically differences attributed to behaviour of the principal or teachers regardless of their demographic variables.

Al-Sharif (2013) conducted a study entitled, "Organizational climate and its relation to job performance: a domain study on faculty members working in public higher education institutions in Benghazi". The sample of the study consisted of all 306 employees in higher education institutions. The study results showed that communication channels were ineffective in higher education institutions, and the nature of such communications was dissatisfied, in addition to the nature of decisions taken, as was being taken by the heads of departments only.

Mohammed (2011) conducted a study entitled, "The organizational climate and its relation to academic performance of university professor". The study sample consisted of 120 university professors. The results of the study showed a correlation between decision making and teacher performance. The most obstacles that can prevent a positive organizational climate at university were financially.

\subsubsection{Foreign Studies}

Davalos (2010) made a study entitled, "The relationship between organizational climate and school performance of Parish Church Association, and Catholic Roman Catholic Teaching System in Manila". The study sample consisted of 152 teachers. The results showed that all parish schools have a positive organizational climate. There was no correlative relationship between organizational climate and job performance of teachers.

Stevan (2010) conducted a study entitled, "The Relationship between School Climate and Teachers' Commitment" in the state of Alabama. The study sample consisted of 67 schools and 1353 volunteer teachers. The results showed a correlative relationship between school climate and teacher commitment, and that school 
weakness has nothing to do with the teacher's commitment.

In a study conducted by Badr (2015) entitled, "A prospective study of the organizational climate in the private schools in the capital city of Amman, in the light of the rules of knowledge management". The sample of the study consisted of 1452 principals and teachers of private schools in Amman. The results showed that the level of organizational climate was high, there were statistically significant differences attributed to gender and years of experience and there were no statistically significant differences due to two variables: scientific position and qualification.

\subsubsection{What Distinguishes This Study from Previous Studies?}

With the exception of Al-Omari\& Al-Ta'ani (2013) study; conducted in the province of Irbid, which may not represent all spectrums of Jordanian society for cultural and social reasons, the two researchers did not find any previous study examined the relationship between the organizational climate and the teachers' job performance.

While the population of Irbid is linked to the relations of relatives, the population of Zarqa is mixed, and belong to all the governorates of Jordan. The reason is that the city of Zarqa is the city of the Jordanian Army families, because Zarqa hosting the training camps. Therefore, the residents of Zarqa represent the entire Jordanian society. This is what distinguishes this study from previous studies.

\section{Methodology}

The study followed correlative descriptive approach as the most appropriate for this type of studies.

\subsection{Population of the Study}

The population of this study consisted of all (150) male and female principals and all (500) male and female teachers of public high schools in Zarqa Education Directorate II, Jordan, who have been working for the academic year 2017-2018.

\subsection{Sample of the Study}

Using the stratified random technique, the study sample consisted of (100) principals and (300) teachers of public secondary schools, from those who are working during the academic year 2016-2017, at Zarqa Education Directorate II, as shown in the following table:

Table (1). Distribution of sample members by job title and sex

\begin{tabular}{|c|c|c|c|}
\hline \multirow[t]{2}{*}{ Job Title } & \multicolumn{2}{|c|}{ Sex } & \multirow[b]{2}{*}{ Total } \\
\hline & Male & Female & \\
\hline Principal & 44 & 56 & 100 \\
\hline Teacher & 132 & 168 & 300 \\
\hline Total & 176 & 224 & 400 \\
\hline
\end{tabular}

\subsection{Study Instrument}

To achieve the study objectives, two instruments were developed, in the light of previous related studies and theoretical literature:

1. A 21-item questionnaire to measure the level of the organizational climate in public secondary schools, divided into three areas: Principal leadership behavior ( 8 items), communication (7 items) and decision-making (8 items).

2. A 21-item questionnaire to measure the teacher job performance, divided into three areas: Administrative domain (8 items), technical domain (9 items) and social domain (4 items).

To answer the items of both questionnaires, the three-choice Likert scale was used: high, medium, and low.

\subsection{Questionnaires Validity}

The two questionnaires were presented to ten arbitrators in educational administration to ensure their validity in terms of construction, language integrity and clarity. The remarks of all arbitrators were taken into consideration.

\subsection{Questionnaires Reliability}

To verify the reliability of both questionnaires, the Cronbach-alpha coefficient was calculated for their domains as shown in the following table. 
Table (2). Cronbach-Alpha Correlation Coefficient for the Instruments

\begin{tabular}{ccc}
\hline Questionnaire & Domain & Cronbach-Alpha Coefficient \\
\hline School & Leadership behavior of principal & 0.752 \\
Organizational & Communication & 0.785 \\
Climate & Decision-making & 0.728 \\
Teachers' & Administrative & 0.736 \\
Job Performance & Technical & 0.743 \\
& Social development & 0.716 \\
\hline
\end{tabular}

\subsection{Study Variables}

The study included the following variables:

- Independent Variable: The level of organizational climate at the public high schools in Jordan.

- Dependent Variable: Teacher job performance at the public high schools in Jordan.

\subsection{Statistical Processing Methods}

To meet study objectives, the Statistical Packages for Social Sciences (SPSS) program was used to analyze data and obtain the results as follows: Frequency and percentages to describe the characteristics of study sample, arithmetic averages and standard deviations to identify responses of sample members on each of the two questionnaires, Pearson Correlation for finding out correlation between variables, and Cronbach's Alpha to verify the stability of the two samples.

In order to classify the level of the schools' organizational climate and the teachers' job performance, the following equation was used:

The highest choice of answer (3), minus the minimum choice of answer (1), divided by the number of options (3). This means: $3-1=2 / 3=1.66$. Accordingly, the values of the three levels are as follows: Low level (Arithmetic average 1.66 or less), medium level (1.67-2.33), and high level (2.34 or above).

\section{Study Results}

The results of the study are presented in accordance with their questions, as follows:

3.1 Results related to question (1): What is the level of organizational climate at public high schools in Jordan from teachers' perspective?

To answer this question, the arithmetical averages and standard deviations of the responses of the study sample members were extracted on the paragraphs of the questionnaire domains. Table (3) illustrates these results:

Table (3). Arithmetical averages, standard deviations, order, and the degree of approval of the sample members at levels of organizational climate at public high schools from teachers' perspective

\begin{tabular}{ccccc}
\hline Domain & $\begin{array}{c}\text { Arithmetical } \\
\text { Average }\end{array}$ & Standard deviation & Order & Degree of approval \\
\hline Communication & 2.18 & 0.499 & 1 & Medium \\
Principal leadership behavior & 2.16 & 0.460 & 2 & Medium \\
Decision making & 2.12 & 0.498 & 3 & Medium \\
Organizational Climate / Total & $\mathbf{2 . 1 5}$ & $\mathbf{0 . 4 1 8}$ & & Medium \\
\hline
\end{tabular}

The results show that the level of the organizational climate in the public high schools in Jordan from teachers' perspective was medium. This result may be attributed to the poor leadership of school principals, the inability of principals to improve the school's internal environment, and the low morale of teachers because of the difficult economic conditions they live in. This result was agreed with the study of Al-Omari and Al-Ta'ani (2013), which showed that organizational support was moderate. In contrast, this result differs with the result of a Bader's study (2015), which showed that the level of organizational climate was high.

The two researchers also extracted the means and the standard deviations of the responses of the study sample members on the paragraphs of each domain, as follows: 


\subsubsection{First Domain: Leadership Behaviour of Principal}

The mean and standard deviations were calculated on the sample members' responses at organizational climate level in the public high schools in Jordan from the teachers' perspective on principals' leadership behaviour, as shown in table (4):

Table (4). Mean, standard deviations and approval order of the sample members' responses at organizational climate level from the teachers' perspective on leadership behaviour of principal

\begin{tabular}{|c|c|c|c|c|c|}
\hline No. & Paragraph & Mean & $\begin{array}{l}\text { Standard } \\
\text { deviation }\end{array}$ & Order & $\begin{array}{l}\text { Degree of } \\
\text { approval }\end{array}$ \\
\hline 7 & Encourages team work among teachers & 2.28 & 0.759 & 1 & Medium \\
\hline 1 & $\begin{array}{l}\text { Interested in organizational structure of the } \\
\text { school }\end{array}$ & 2.24 & 0.741 & 2 & Medium \\
\hline 6 & Delegating his power to teachers & 2.23 & 0.737 & 3 & Medium \\
\hline 4 & $\begin{array}{l}\text { Using efforts to inform teachers about anything } \\
\text { new and updated }\end{array}$ & 2.22 & 0.766 & 4 & Medium \\
\hline 5 & $\begin{array}{l}\text { Providing a positive organizational climate } \\
\text { within the school }\end{array}$ & 2.18 & 0.779 & 5 & Medium \\
\hline 8 & $\begin{array}{l}\text { Discussing decisions with teachers before taking } \\
\text { them }\end{array}$ & 2.06 & 0.738 & 6 & Medium \\
\hline 2 & Treating teachers as classmates & 2.03 & 0.747 & 7 & Medium \\
\hline 3 & $\begin{array}{l}\text { Encouraging individual and collective initiatives } \\
\text { by teachers }\end{array}$ & 2.02 & 0.818 & 8 & Medium \\
\hline & Total & 2.16 & 0.460 & & Medium \\
\hline
\end{tabular}

Table (4) shows that the mean of the organizational climate in the public secondary schools in Jordan from the point of view of the teachers regarding the leadership behaviour of the school principal was medium. The average values of this domain ranged between $(2.02-2.28)$, and all of these items was medium.

\subsubsection{Second Domain: Communication}

The mean and standard deviations were calculated on the sample members' responses at organizational climate level in the public high schools in Jordan from the teachers' perspective on principals' communication, as shown in table (5):

Table (5). Mean, standard deviations and approval order of the sample members' responses at organizational climate level from the teachers' perspective on principals' communication

\begin{tabular}{|c|c|c|c|c|c|}
\hline No. & Paragraph & Mean & $\begin{array}{l}\text { Standard } \\
\text { deviation }\end{array}$ & Order & $\begin{array}{l}\text { Degree of } \\
\text { approval }\end{array}$ \\
\hline 14 & Teachers exchange home visits & 2.30 & 0.739 & 1 & Medium \\
\hline 12 & $\begin{array}{l}\text { Atmosphere of friendship and brotherhood } \\
\text { between teachers }\end{array}$ & 2.20 & 0.751 & 2 & Medium \\
\hline 10 & $\begin{array}{l}\text { Teachers communicate with each other in } \\
\text { affection and understanding }\end{array}$ & 2.18 & 0.763 & 3 & Medium \\
\hline 11 & Principals listen to teachers when talking to them & 2.16 & 0.755 & 4 & Medium \\
\hline 13 & Teachers forgive each other's mistakes & 2.15 & 0.756 & 5 & Medium \\
\hline 9 & $\begin{array}{l}\text { Teachers are allowed to communicate directly } \\
\text { with them }\end{array}$ & 2.12 & 0.762 & 6 & Medium \\
\hline 15 & Teachers respect each other & 2.12 & 0.755 & 6 & Medium \\
\hline & General average & 2.18 & 0.499 & \multicolumn{2}{|c|}{ Medium } \\
\hline
\end{tabular}

Table (5) shows that the mean of the organizational climate in the public secondary schools in Jordan from the point of view of the teachers regarding the principals' communication was medium. The average values of this domain ranged between $(2.12-2.30)$, and all of these items was medium. 


\subsubsection{Third Domain: Decision-Making}

The means and standard deviations were calculated on the sample members' responses at organizational climate level in the public high schools in Jordan from the teachers' perspective on the decision making process, as shown in table (6):

Table (6). Mean, standard deviations and approval order of the sample members' responses at organizational climate level from the teachers' perspective regarding decision making process

\begin{tabular}{clcccc}
\hline No. & \multicolumn{1}{c}{ Paragraph } & Mean & $\begin{array}{c}\text { Standard } \\
\text { deviation }\end{array}$ & Order & $\begin{array}{c}\text { Degree of } \\
\text { approval }\end{array}$ \\
\hline 20 & $\begin{array}{l}\text { The school principal discusses decisions with } \\
\text { teachers before they are implemented }\end{array}$ & 2.21 & 0.742 & 1 & Medium \\
21 & $\begin{array}{l}\text { The school principal makes sure that his or her } \\
\text { decisions are in the interest of the school }\end{array}$ & 2.20 & 0.777 & 2 & Medium \\
16 & $\begin{array}{l}\text { The Principal delegates some of his powers to } \\
\text { teachers } \\
\text { The principal benefits from experiences of previous }\end{array}$ & 2.10 & 0.740 & 3 & Medium \\
17 & 2.07 & 0.783 & 4 & Medium \\
18 & $\begin{array}{l}\text { The principal makes decisions based on appropriate } \\
\text { and sufficient information }\end{array}$ & 2.06 & 0.734 & 5 & Medium \\
19 & $\begin{array}{l}\text { School principal forces teachers to implement } \\
\text { decisions }\end{array}$ & 2.05 & 0.807 & 6 & Medium \\
\hline$\quad$ Total & $\mathbf{2 . 1 2}$ & $\mathbf{0 . 4 9 8}$ & & Medium \\
\hline
\end{tabular}

Table (6) shows that the mean of the organizational climate in the public secondary schools in Jordan from the point of view of the teachers regarding decision making process was medium. The average values of this domain ranged between $(2.05-2.21)$, and all of these items was medium.

3.2 Results of the Second Question: What is the Level of Teachers' Job Performance at Public High Schools in Jordan from Their Principals' Perspective?

To answer this question, means and standard deviations of the principals' responses regarding teachers' job performance were calculated, as shown in table (7):

Table (7). Means, standard deviations, and approval order of principals' perceptions regarding their teachers' job performance

\begin{tabular}{ccccc}
\hline Domain & Mean & Standard deviation & Order & Degree of approval \\
\hline Social development & 2.19 & 0.522 & 1 & Medium \\
Technical & 2.13 & 0.422 & 2 & Medium \\
Administrative & 2.12 & 0.421 & 3 & Medium \\
Overall job performance & $\mathbf{2 . 1 3}$ & $\mathbf{0 . 3 6 9}$ & & Medium \\
\hline
\end{tabular}

Table (7) shows that the level of teachers' job performance at public high schools in Jordan from their principals' perspective was medium, with a mean of 2.13 and standard deviation of 0.369 . It shows also that all domains have medium approval levels. The social domain scored the highest mean (2.19), followed by technical domain with an average of 2.13, and finally, the administrative domain ranked third and last, with a mean of 2.12.

This result differs with the results of Brinda (2014), whose showed that the organizational climate affects significantly on work motivations with respect to teachers, and also differs with Hamad study (2016), whose results showed that the performance was high.

The two researchers also extracted the means and the standard deviations of the responses of the study sample members on the paragraphs of each domain, as follows:

\subsubsection{First Domain: Administrative:}

To answer this question, means, standard deviations and the approval order were calculated on level of 
performance of high school teachers in Jordan regarding administrative domain as shown in the following table:

Table (8). Means, standard deviations and rank of Jordanian teacher job performance at high schools with respect to administrative domain

\begin{tabular}{clcccc}
\hline No. & \multicolumn{1}{c}{ Paragraph } & Mean & S.D & Order & Degree \\
\hline 3 & Run school meetings seriously & 2.31 & 0.659 & 1 & Medium \\
1 & $\begin{array}{l}\text { Determines tasks required by teachers according to } \\
\text { their abilities }\end{array}$ & 2.15 & 0.668 & 2 & Medium \\
6 & Follow working hours of teachers in school & 2.11 & 0.733 & 3 & Medium \\
5 & Shared with teachers in decision-making & 2.09 & 0.755 & 4 & Medium \\
8 & $\begin{array}{l}\text { Teachers are encouraged to self-assess their schoolwork } \\
\text { and achievements }\end{array}$ & 2.09 & 0.735 & 5 & Medium \\
& Monitor special notes of teachers according to records & 2.08 & 0.723 & 6 & Medium \\
7 & for each of them & 2.05 & 0.672 & 7 & Medium \\
2 & Know teaching competencies of teachers & 2.05 & 0.734 & 8 & Medium \\
4 & Establish positive relationships with teachers & $\mathbf{2 . 1 2}$ & $\mathbf{0 . 4 2 1}$ & & Medium \\
\hline
\end{tabular}

Table (8) shows that the level of teachers' job performance at public high schools in Jordan from their principals' perspective regarding administrative domain was medium, with a mean of 2.12 and standard deviation of 0.421 . It shows also that all items have medium approval levels, and ranged between 2.05 and 2.31 .

\subsubsection{Second Domain: Technical}

To answer this question, means, standard deviations were calculated of teachers' job performance regarding technical domain. Table (9) illustrated these results:

Table (9). Means, standard deviations, and order of teacher job performancein respect to technical domain

\begin{tabular}{|c|c|c|c|c|c|}
\hline No. & Paragraph & Mean & SD & Order & Degree \\
\hline 11 & Develop plans to exchange visits with teachers & 2.27 & 0.712 & 1 & Medium \\
\hline 10 & Diagnoses training needs of teachers & 2.16 & 0.751 & 2 & Medium \\
\hline 12 & $\begin{array}{l}\text { Ensure that experiences with other principals in other } \\
\text { schools are shared }\end{array}$ & 2.15 & 0.718 & 3 & Medium \\
\hline 13 & Follow up school administration & 2.14 & 0.735 & 4 & Medium \\
\hline 16 & $\begin{array}{l}\text { Ensure that means to complement school curriculum } \\
\text { are provided }\end{array}$ & 2.12 & 0.760 & 5 & Medium \\
\hline 15 & $\begin{array}{l}\text { Interested in training teachers and increasing their } \\
\text { experience }\end{array}$ & 2.11 & 0.733 & 6 & Medium \\
\hline 9 & $\begin{array}{l}\text { Teachers are informed of school curriculum changes } \\
\text { on an ongoing basis }\end{array}$ & 2.09 & 0.758 & 7 & Medium \\
\hline 17 & $\begin{array}{l}\text { Follow teachers in analysis curricula and books } \\
\text { developed }\end{array}$ & 2.08 & 0.722 & 8 & Medium \\
\hline 14 & Provides moral incentives for teachers & 2.06 & 0.738 & 9 & Medium \\
\hline & Overall Technical Domain & 2.13 & 0.422 & & Medium \\
\hline
\end{tabular}

Table (9) demonstrates that the overall level of technical domain was medium, with a value of 2.13 and standard deviation of 0.422. Furthermore, the means of the nine items of this domain were ranged between 2.06-2.27, which means that all of these items are medium.

\subsubsection{Third Domain: Social}

To answer this question, means and standard deviations of the responses of the sample members were calculated for the social domains. The result showed that the total mean of this domain was 2.19 with a standard deviation of 0.522 , corresponding to the medium level, as showed in table (10): 
Table (10). Means, standard deviations, and approval order of sample members on job performance of Jordanian high school teachers on social domain

\begin{tabular}{|c|c|c|c|c|c|}
\hline No. & Paragraph & Means & SD & Order & Degree \\
\hline 21 & $\begin{array}{l}\text { Provides opportunity for local community to take advantage of } \\
\text { school facilities, if necessary }\end{array}$ & 2.32 & 0.703 & 1 & Medium \\
\hline 18 & Forms parents' councils & 2.27 & 0.717 & 2 & Medium \\
\hline 20 & Participates with local community in school activities & 2.14 & 0.685 & 3 & Medium \\
\hline 19 & $\begin{array}{l}\text { Involves the local community in developing vision, mission and } \\
\text { goals of the school }\end{array}$ & 2.04 & 0.737 & 4 & Medium \\
\hline & Overall Social Domain & 2.19 & 0.522 & & Medium \\
\hline
\end{tabular}

Table (10) shows that the means of the four items of social domain were ranged between $2.04-2.32$, and all of these means are located within the medium level. Item 21 (Provides opportunity for local community to take advantage of school facilities, if necessary) scored the highest mean (2.27).

3.3 Results Related to Question 3: Is There a Statistically Significant Relationship $(\&=0.05)$ Between the Level of Organizational Climate at Public High Schools in Jordan, and the Level of Job Performance of Teachers in These Schools?

To answer this question, the Pearson test was applied between the three domains of organizational climate in the public high schools in Jordan and the three domains of teacher job performance in these schools. Table (11) illustrates these results:

Table (11). Pearson test results to measure the correlation between organizational climate domains at the Jordanian public high schools and their teachers' job performance

\begin{tabular}{|c|c|c|c|c|c|}
\hline \multirow{2}{*}{\multicolumn{2}{|c|}{$\begin{array}{c}\text { Variable } \\
\text { Job Performance }\end{array}$}} & \multicolumn{4}{|c|}{ Organizational climate } \\
\hline & & $\begin{array}{c}\text { Leadership } \\
\text { behavior }\end{array}$ & Communication & Decision-Making & Overall \\
\hline \multirow{2}{*}{ Administrative } & $\begin{array}{l}\text { Correlation } \\
\text { coefficient }\end{array}$ & $0.445 * *$ & $0.399 * *$ & $0.400 * *$ & $\begin{array}{c}0.482 \\
* *\end{array}$ \\
\hline & $\begin{array}{c}\text { Significance } \\
\text { Level }\end{array}$ & 0.000 & 0.000 & 0.000 & 0.000 \\
\hline \multirow{2}{*}{ Technical } & $\begin{array}{l}\text { Correlation } \\
\text { coefficient }\end{array}$ & $0.406 * *$ & $0.383 * *$ & $0.326 * *$ & $\begin{array}{c}0.433 \\
* *\end{array}$ \\
\hline & $\begin{array}{c}\text { Significance } \\
\text { Level }\end{array}$ & 0.000 & 0.000 & 0.000 & 0.000 \\
\hline \multirow{2}{*}{ Social } & $\begin{array}{l}\text { Correlation } \\
\text { coefficient }\end{array}$ & $0.406 * *$ & $0.331 * *$ & $0.343 * *$ & $\begin{array}{c}0.419 \\
* *\end{array}$ \\
\hline & $\begin{array}{c}\text { Significance } \\
\text { Level }\end{array}$ & 0.000 & 0.000 & 0.000 & 0.000 \\
\hline \multirow{2}{*}{ Overall } & $\begin{array}{c}\text { Correlation } \\
\text { coefficient }\end{array}$ & $0.502 * *$ & $0.450 * *$ & $0.426 * *$ & $\begin{array}{c}0.535 \\
* *\end{array}$ \\
\hline & $\begin{array}{c}\text { Significance } \\
\text { Level }\end{array}$ & 0.000 & 0.000 & 0.000 & 0.000 \\
\hline
\end{tabular}

Table (11) shows that all values of significance levels among organizational climate and job performance domains were less than 0.05 . It also showed that there is a positive correlation between organizational climate and job performance. This means that the higher the level of any organizational climate at public high schools in Jordan, the higher levels of performance of teachers in these schools, and vice versa.

This result is differing from the results of Davalos (2010), whose results showed no correlative relationship between organizational climate and job performance of teachers. 


\section{Result Discussion}

\subsection{Discussion of the Result to Question (1) What is the Level of Organizational Climate at Public High Schools} in Jordan from Teachers' Perspective?

The results show that the level of the organizational climate in the public high schools in Jordan from teachers' perspective was medium. This result may be attributed to the poor leadership of school principals, the inability of principals to improve the school's internal environment, and the low morale of teachers because of the difficult economic conditions they live in.

\subsubsection{First domain: Leadership behaviour of principal}

This result can be attributed to poor preparation and weak in-service training of school principals for their leadership duties such as: Encouraging team work, delegating of power, updating teachers' knowledge, enhancing decision making process, treating teachers as colleagues, and encouraging individual and collective initiatives by teachers. This result differed with Taher (2015), whose results showed a negative orientation to some dimensions of organizational climate such as leadership style and participation in decision-making.

\subsubsection{Second Domain: Communication}

This result might be attributed to the fact that teachers seek to strengthen social ties between them to create a joyful atmosphere, spread love and affection, strengthen fellowship among them, and make new long-term friendships.

\subsubsection{Third Domain: Decision-Making}

This result might be attributed to the fact that one of the most important tasks assigned to the school principal is decision-making to achieve the objectives of the learning process. In addition, the high school's principal ensures positive participation of teachers in decision-making because they represent one team within the school. The decision-making process is no longer confined to the principal alone, but to the teacher's help. Teachers' involvement in the process reinforces the school's organizational climate, stimulates their career performance and develops their efforts.

\subsection{Results of the Second Question: What is the Level of Teachers' Job Performance at Public High Schools in Jordan From Their Principals' Perspective?}

Table (7) shows that the level of teachers' job performance at public high schools in Jordan from their principals' perspective was medium, with a mean of 2.13 and standard deviation of 0.369 . It shows also that all domains have medium approval levels. The social domain scored the highest mean (2.19), followed by technical domain with an average of 2.13, and finally, the administrative domain ranked third and last, with a mean of 2.12.

This result may be attributed to poor teacher preparation, lack of training programs, poor educational supervision and lack of accountability. This result differs with the results of Brinda (2014), whose showed that the organizational climate affects significantly on work motivations with respect to teachers, and also differs with Hamad study (2016), whose results showed that the performance was high.

The two researchers also extracted the means and the standard deviations of the responses of the study sample members on the paragraphs of each domain, as follows

\subsubsection{First Domain: Administrative}

This result may be attributed to the fact that school meetings are of great importance in terms of organizing meetings by school, improving the day course of school, exchange ideas and experiences, and learning about conditions of the school. These meetings may be periodic, specialized or open; in addition, that management matter can be criticized.

\subsubsection{Second Domain: Technical}

This result may be attributed to the fact that the high school principal tends to develop plans to exchange visits with teachers. He aims by which to exchange views on curriculum, finding solutions to classroom problems facing teachers, raising efficiency of teachers by applying new teaching methods, using appropriate pedagogical techniques and deepening respect for them.

The paragraph that received the lowest average arithmetic was attributed to the lack of guidance by principal to high school teachers, the lack of channels of communication between them, the incentives no fit with the effort exerted by teachers, failure to involve them in development of vision and mission of the school, lack of knowledge of school principal to exploit potentials of teachers by using deterrent and punishment. However, negatives became more than positives that moral benefits reduced, and negatively impacted teachers. 


\subsubsection{Third domain: Social}

Such result may be attributed to the fact that the Jordanian high school principal is endeavour to ensure that the relationship with community is strong through community participation in school seminars and conferences, using the school facilities such as playgrounds for children during holidays.

In contrast, item 19; (Involves the local community in developing vision, mission and goals of the school), has obtained the lowest mean (2.04) with (0.522) standard deviation. This finding may be due to the fact that some high school principals in Jordan do not activating the role of the community in communicating with the school and neglect community initiatives towards school. This may also be due to the fact that this community sometimes lacks sufficient awareness of the role it should play in cooperating with the school and shows apathy to school issues.

4.3 Results Related to Question 3: Is There a Statistically Significant Relationship ( $\&=0.05)$ Between the Level of Organizational Climate at Public High Schools in Jordan, And the Level of Job Performance of Teachers in These Schools?

This result may be attributed to the importance of positive organizational climate as a catalyst for supporting high school teachers. Good school management pays attention to the needs of teachers and tries hard to achieve them by employing them within available resources of all kinds. The prudent management is working to make maximum use of teachers' efforts, create the appropriate organizational environment so as to be reflected on educational outputs. The more interested the school to satisfy the needs of high school teachers, the better their ability to give and produce, and increase their organizational loyalties, and job performances. This matter was confirmed by many studies, such as Abu Sweireh (2010), which made sure that there is a positive organizational climate at the university, a correlative relationship organizational climate and job performance of the staff. The study of Stevan (2010) showed that there was a correlative relationship between the organizational school climate and commitment of teachers, and that school weakness has nothing to do with the teacher's commitment. The study of Mohammed (2011) showed that there is a correlative relationship between decision-making process and level of job performance of teachers. However, the financial constraints were the main factor to prevent the existing of a positive organizational climate at the university. It agreed with the study of Hamad (2016) that showed that there is a correlative relationship between performance commitment, realized organizational support, and job performance in academic institutions. The performance commitment and organizational support affect the job performance of administrators.

\subsection{Recommendations}

Based on findings of this study, the researchers recommend the following:

1) The results of the first question indicated that the level of organizational climate at public high schools in Jordan from teachers' perspective was medium. Accordingly, the researchers recommend that policy makers at the Ministry of Education should focus on finding an appropriate and positive organizational climate for teachers, and holding training course on educational communication for principals.

2) The results showed that teachers' job performance at public high schools in Jordan from principals' perspective was medium. Accordingly, it was recommended that top level management at the Ministry of Education in Jordan must pay attention to enhance all teachers' duties, including teaching practices, by conducting training courses for those teachers.

\section{References}

Abu Sawirh, A. (2010). Impact of Organizational climate on Job Performance of Administrators at Islamic University of Gaza. Journal of the Islamic University (Humanity studies), 18(2), 1147-1214.

Al-Qariuti, M. (2000). Organizational Behavior: Studying individual and Collective Human Behavior in Different Organizations. Amman: Dar Al Shorouk.

Badr, A. (2015). A Prospective Study of Organizational climate at Private Schools in Amman, in the light of Knowledge Management Rules. Unpublished Ph.D. thesis, University of Jordan, Amman, Jordan.

Brenda, T. (2014). Organizational climate and Teachers Work Motivation: A Case Study of Selected School in Prachinburi. Master Thesis. Theresa International College, Thailand.

Chicken, M. (2011). Organizational climate and its Relation with Academic Job Performance of University Professor. Unpublished Master Thesis, Qasidi University, Merbah, Warfala, Algeria.

Davalos, D. (2010). Behavior- Based Organizational climate and School Performance of Manila Archdiocesan 
Parochial School Association (Mapsa) Roman Catholic Archdiocese of Manila Educational System (Rcames), Ohio University, USA.

Ghareeb, B. (2005). School culture. Amman: Dar Al-Fikr.

Hamad, M. (2016). Impact of Functional Correlation and Organizational Structure on Job Performance in Palestinian Academic Institutions. Unpublished MA, Islamic University, Gaza, Palestine.

Hammadat, M. (2008). Organizational Behavior and Future Challenges in Educational Institutions. Amman: Dar Al-Hamed.

Omri, H., \& Ta'ani, S. (2013). Impact of Organizational climate on Job Performance of Teachers in Irbid Governorate. Journal of the Faculty of Education, Banha, 96(1), 113-136.

Sharif, H. (2013). Organizational climate and its Relation to Job Performance: A Field Study on Faculty Members Working for Higher Education Institutions in Benghazi. Unpublished Master Thesis, Benghazi University, Faculty of Economics, Libya.

Stevan, M. (2010). Organizational climate and Teaching Commitment. Ph.D. Thesis, University of Alabama, Tuscal Coosa, Alabama.

Taher, A. (2015). Impact of Organizational Climate Dimensions on Work Stress in University Institutions. Journal of Economic Sciences, 16(2), 70-100.

\section{Copyrights}

Copyright for this article is retained by the author(s), with first publication rights granted to the journal.

This is an open-access article distributed under the terms and conditions of the Creative Commons Attribution license (http://creativecommons.org/licenses/by/4.0/). 